PERM JOURNAL OF PETROLEUM AND MINING ENGINEERING ВЕСТНИК ПНИПУ. ГЕОЛОГИЯ. НЕФТЕТАЗОВОЕ И ГОРНОЕ ДЕЛО ISSN 2224-9923 Volume/Tom 19 №4 2019

http://vestnik.pstu.ru/geo/

UDC 622.276:551.734.5

Article / Статья

(C) PNRPU / ПНИПУ, 2019

\title{
GEOLOGY ASPECTS OF UPPER DEVONIAN REEF DEPOSITS IN TIMAN-PECHORA OIL AND GAS BEARING PROVINCE
}

\author{
N.E. Sosnin, T.A. Kazakova, S.G. Filipyeva, D.I. Vasyanina, I.S. Batova
}

Kama research institute for integrated research of deep and superdeep wells (15 Krasnoflotskaya st., Perm, 614016, Russian Federation)

\section{ОСОБЕННОСТИ ГЕОЛОГИЧЕСКОГО СТРОЕНИЯ ВЕРХНЕДЕВОНСКИХ РИФОГЕННЫХ ОТЛОЖЕНИЙ ТИМАНО-ПЕЧОРСКОЙ НЕФТЕГАЗОНОСНОЙ ПРОВИНЦИИ}

\section{Н.Е. Соснин, Т.А. Казакова, С.Г. Филипьева, Д.И. Васянина, И.С. Батова}

Камский научно-исследовательский институт комплексных исследований глубоких и сверхглубоких скважин (614016, Россия, г. Пермь, ул. Краснофлотская, 15)

Received / Получена: 05.06.2019. Accepted / Принята: 01.11.2019. Published / Опубликована: 27.12.2019

\section{Key words:}

Timan-Pechora oil and gas bearing province, core, profile, well, organic matter, bitumoid, oil source rocks, Rock Eval pyrolysis, R spectrometry, re-interpretation, geophysical well logging, porosity, reservoir.
Ключевые слова: Тимано-Печорская нефтегазоносная провинция, керн, разрез, скважина, органическое вещество, битумоид, нефтематеринские породы, пиролиз Rock-Eval, ИК-спектрометрия, переинтерпретация, геофизические исследования скважин, пористость, коллектор
The paper analyzes the structure of Upper Devonian reef strata within Moroshkinsky, Ust-Tsilemsky and Severo-Tebuksky reference sites located in the territory of the Komi Republic and Nenets Autonomous Okrug. Based on the re-interpretation of the materials of geophysical well logging involving lithologic description of core and results of its laboratory studies, a detailed analysis of the structure of Domanic-Famenian part of the profile has been made, and a correlation pattern for deep well profiles has been drawn. As a result of well log correlation, some of the stratigraphic boundaries have been updated, the scope of lithologic and stratigraphic subdivisions has been determined, reference bands with good visibility on geophysical diagrams and easily traceable carbonate formations known to geologists as $\mathrm{F}_{1}, \mathrm{~F}_{2}, \mathrm{~F}_{3}, \mathrm{~F}_{4}, \mathrm{~F}_{5}$, as well as inter-formation bands, have been specified.

The paper contains the results of a geochemical study of the Upper Devonian reef deposits of the wells drilled in the territory of Moroshkinsky, Ust-Tsilemsky and Severo-Tebuksky sites. It presents content distribution of organic carbon, chloroform and alcohol-benzol extracted bitumoids in the rocks of certain well horizons, and describes oil generation potential of the rocks on the basis of pyrolytic data.

Based on the comprehensive analysis of the results of laboratory core analysis and materials of production log tests, reservoir quality discrimination has been performed, an evaluation of their quantitative parameters and fluid content has been made. Porosity factor has been selected as the criterion for evaluation of reservoir properties of the rocks. Determination of porosity by neutron gammaray logging has been performed following the method of two guide formations using the dependencies developed by JSC KamNIIKIGS. For evaluation of quantitative parameters of carbonate reservoirs, the results of standard core analysis were used: effective porosity, absolute permeability to gas, and volumetric density. The results of the research can be used during prospecting and exploration in the territory of the three reference sites of interest. Северо-Тэбукского эталонных участков, расположенных на территории Республики Коми и Ненецкого автономного округа. На основе переинтерпретации материалов геофизических исследований скважин с привлечением литологического описания керна и результатов его лабораторных исследований проведена детализация строения доманиково-фаменской части разреза, приведена схема корреляции разрезов глубоких скважин. В результате корреляции разрезов откорректированы некоторые стратиграфические границы, определен объем литолого-стратиграфических подразделений, выделены реперные пачки, хорошо отображаемые на геофизических диаграммах, и прослеживаемые карбонатные пласты, известные геологам как $\Phi_{1}, \Phi_{2}, \Phi_{3}, \Phi_{4}, \Phi_{5}$, а также межпластовые пачки.

В данной работе приведены результаты геохимических исследований верхнедевонских рифогенных отложений скважин, пробуренных на территории Морошкинского, Усть-Цилемского и Северо-Тэбукского участков. Представлено распределение содержания органического углерода, хлороформенного и спиртобензольного битумоидов в породах отдельных горизонтов скважин, а также охарактеризован нефтегенерационный потенциал пород по пиролитическим данным.

На основании комплексного анализа результатов лабораторно-аналитических исследований керна и материалов промыслово-геофизических исследований выполнено выделение коллекторов, проведена оценка их количественных
параметров и характера насыщенности. Критерием для оценки коллекторских свойств пород выбран коэффициент пористости. Определение пористости по нейтронному гамма-каротажу проведено способом двух опорных пластов с применением зависимостей АО «КамНИИКИГС». Для оценки количественных параметров карбонатных коллекторов использованы результаты стандартных исследований керна: открытая пористость, абсолютная газопроницаемость, объемная плотность. Результаты проведенных исследований могут быть использованы при проведении поисковоразведочных работ на территории трех рассмотренных эталонных участков.

Nikolay E. Sosnin (AuthorID in Scopus: 55750130100) - PhD in Geology and Mineralogy, Head of the Department of the Volga-Urals Oil and Gas Potential (tel.: +007963012 15 52, e-mail: kamniikigs@rusgeology.ru).

Tatyana A. Kazakova - Lead Engineer (tel.: +00791259302 32, e-mail: tkazakova 1946@mail.ru).

Svetlana G. Filipyeva - Deputy Head of the Department of the Volga-Urals Oil and Gas Potential (tel.: +007 90280007 23, e-mail: sgfq@mail.ru). The contact person for correspondence.

Daria I. Vasyanina - Senior Researcher (tel.: +007 9226475 215, e-mail: geochim@niikigs.ru).

Iraida S. Batova - Researcher (tel.: +007912 78911 06, e-mail: batovaira@yandex.ru).

Соснин Николай Евгеньевич - кандидат геолого-минералогических наук, начальник отдела нефтегазоносности Волго-Урала (тел.: +007 9630121552 , e-mail: kamniikigs@rusgeology.ru).

Казакова Татьяна Александровна - ведущий инженер (тел.: +007 91259302 32, e-mail: tkazakova 1946@mail.ru)

Филипьева Светлана Геннадьевна - заместитель начальника отдела нефтегазоносности Волго-Урала (тел.: +007 9028000723 , e-mail: sgfq@mail.ru).

Контактное лицо для переписки.

Васянина Дарья Ильинична - старший научный сотрудник (тел.: +007 9226475 215, e-mail: geochim@niikigs.ru)

Батова Ираида Серапионовна - научный сотрудник (тел.: +007 91278911 06, e-mail: batovaira@yandex.ru) 


\section{Introduction}

The paper presents the results of a detailed structural analysis of the Domanic-Famenian part of the geological profile in the territory of Moroshkinsky, Ust-Tsilemsky and Severo-Tebuksky reference sites. The study is based on the conducted laboratory core analysis, as well as analysis, generalization and partial re-interpretation of available geological and geophysical information concerning the Upper Devonian reef strata.

The region under research is located in the north of the Timan-Pechora oil and gas bearing province, in the territory of Nenets Autonomous Okrug and the Komi Republic (fig. 1). Tectonically the Moroshkinsky site is situated in Denisovskaya depression, Ust-Tsilemsky site is in IzhmaPechorskaya depression at the junction of Izhemskaya and Yersinskaya terrace. Severo-
Tebuksky site is located in Izhma-Pechorskaya depression in the territory of the Timan Ridge, Neritskaya terrace and Omra-Lyzhskaya saddle.

\section{Well Log Correlation}

The Upper Devonian reef strata in TimanPechora province is a promising oil prospecting area, which is justified by actual results of earlier prospecting and exploration work. In the immediate vicinity of the sites of interest are hydrocarbon reservoirs where commercial fields are in part associated with the Upper Devonian deposits. In particular, Moroshkinsky site neighbors with Komandirshorskoye, Severo-Komandirshorskoye, Kharyaginskoye and Srednekharyaginskoye fields, Ust-Tsilemsky site - with Nizevoye and YuzhnoNizevoye fields, Severo-Tebuksky site - with Zapadno-Tebukskoye field.

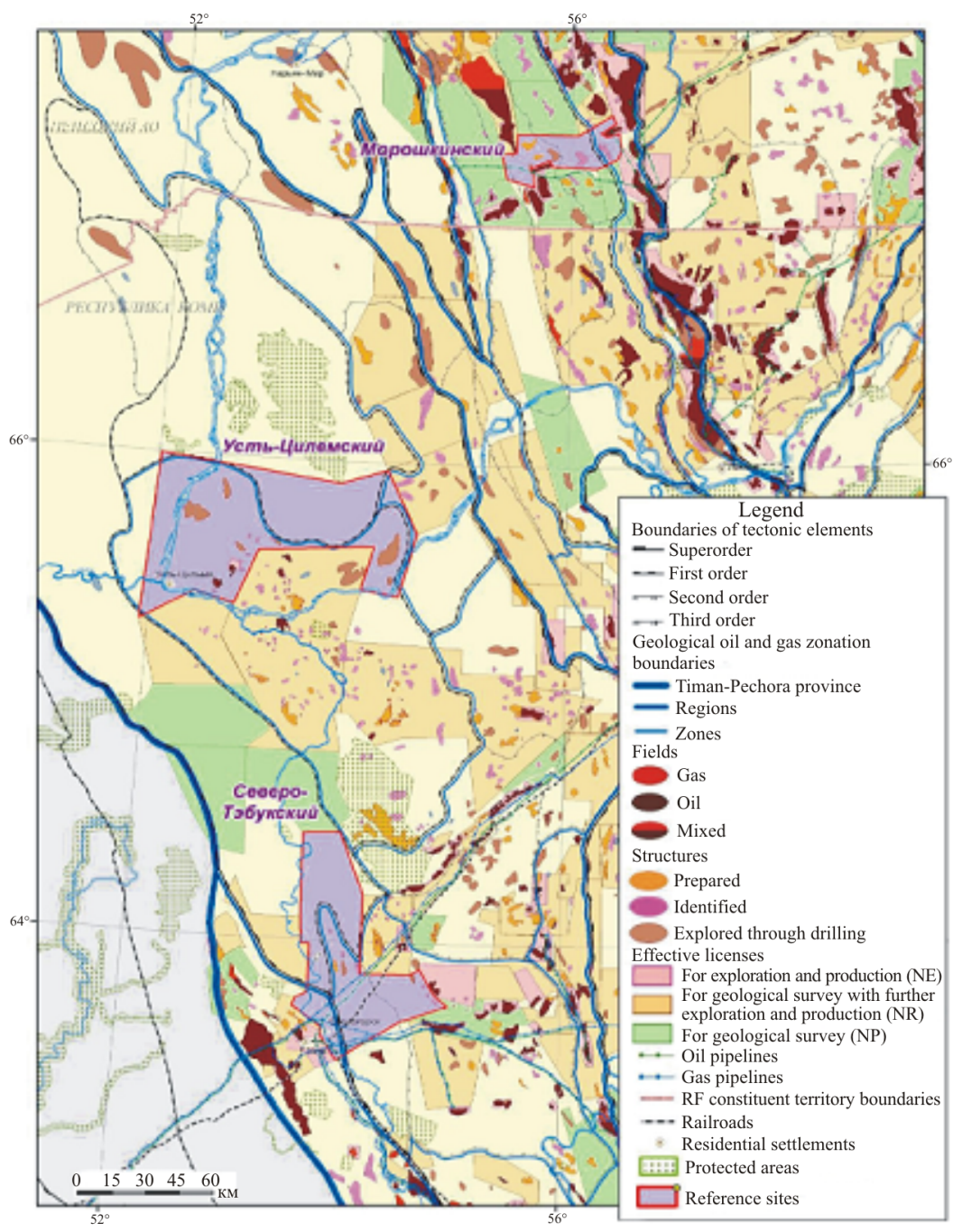

Fig. 1. Location of reference sites on an overview map 
The sedimentary profile under research belongs to the Domanic-Tournaisian carbonate oil and gas play, in most of its wells encompassing the profile from the Domanic horizon of the Middle Frasnian substage to the Numylg horizon of the Upper Famenian substage inclusive $[1,2]$. Some of the wells also have Tournaisian stage deposits. In the territories of Moroshkinsky, Ust-Tsilemsky and Severo-Tebuksky sites, the predominantly carbonate Domanic-Famenian stratum is virtually omnipresent. The deposits are vastly variable in terms of stratigraphic completeness of the profile, lithologic composition and thickness.

In order to produce a more exhaustive development concept of the Upper Devonian deposits and to perform a high quality well correlation, the strata survey included additional information concerning the 22 wells located in the vicinity of site boundaries. The profile has been examined on the basis of the principle of correlation between the strata with diverse facies developed by J.L. Wilson [3] and proposed for TimanPechora province by M.M. Grachevsky [4] taking into account the results of research by B.P. Bogdanov $[5,6]$, L.A. Gobanov [7], L.V. Parmuzina [8], A.V. Solomatin [9], V.S. Tsyganko, P.A. Beznosov [10], V.Vl. Menner [11], E.L. Petrenko [12, 13], Z.P. Yuryeva [14, 15], A.V. Durkina [16].

As a result of the conducted well log correlation, some of the stratigraphic boundaries have been updated, the scope of lithologic and stratigraphic subdivisions has been determined. The research has specified reference bands with a good visibility on geophysical diagrams and easily traceable carbonate formations identified as F1, F2, F3, F4, F5, as well as inter-formation bands. Fig. 2 shows the correlation pattern for profiles of wells drilled in the territory of Ust-Tsilemsky site.

For correlation patterns, reference to facial zones was based on [17] and studies performed in LLC TP NIC [18].

\section{Ust-Tsilemsky Site}

In Moroshkinsky site, the oil and gas play is represented by the Domanic horizon of the Middle Frasnian substage, Vetlasian, Sirachoy, Evlanov and Liven horizons of the Middle Frasnian substage, the Lower and Middle Famenian substages and the undivided Upper Famenian deposits of the ZelenetsNumylg age. The play has been fully uncovered by drilling in the site with two wells: No. 2 and No. 3 Severo-Komandirshorskaya. Its thickness ranges insignificantly and amounts to 934 and $936 \mathrm{~m}$ respectively. Well profiles in the interval under study can be quite successfully correlated on diagrams obtained by geophysical well logging. The Volgograd horizon of the Lower Famenian substage can be easily distinguished in the nuclear logging and apparent resistivity (AR) diagrams, with a clearly discernible clayey band in its top. Another discernible band is that of the terrigenous rocks comprising the Vetlasian horizon, along with the clayey carbonate bands in deposits of the Yelets and Zelenets-Numulg horizons. In the profile of No.2 Severo-Komandirshorskaya well, Timan age of deposits has been confirmed by occasional brachiopod findings in the interval from 4252.1 to $4257.1 \mathrm{~m}$ and the Sargayev horizon bottom has been updated. Absence of faunistic age data prevents from specifying the stratigraphic nature of the clayey band with identical geophysical properties found in the profiles of No.2 Severo- Komandirshorskaya well in the interval of 3273 to $3286 \mathrm{~m}$, of No. 31 Moroshkinskaya well in the interval of 3198 to $3212 \mathrm{~m}$ and of No. 144 Srednekharyaginskaya well in the interval of 2813 to $2825 \mathrm{~m}$. The band has been tentatively qualified as Tournaisian.

The strata under research can be distinguished by three facial types of deposits. Formations of the Domanic horizon have emerged in the development zone of reef systems of condensed (Domanicoid) deposits and filling strata. The terrigenous deposits of the Vetlasian horizon are represented by sediments of filling strata in relatively deep-water Domanicoid (condensed) facies. The Evlanov-Numylg interval of the profile is represented by shallow marine shelf deposits. In Evlanov, Liven and Volgograd horizons, terrigenous rocks prevail, whereas Zadonian, Yelets, Ust-Pechora and Zelenets-Numylg horizons are mostly carbonate.

In Ust-Tsilemsky site, the play of interest is represented by the Middle and Upper substage of the Frasnian stage and the Lower Famenian substage. Deposits of the Domanic horizons are well-developed throughout the entire area and correspond to the two lithofacial zones: shallow marine shelf carbonate formation zone (No. 1 UstTsilemskaya well and No. 40 Khabarikhinskaya well) and development zone of reef systems of condensed (Domanicoid) deposits and filling strata 
(region of No.1-5 wells of Nizevaya area, No. 1 well of Brykalanskaya area and No. 1 of Dvoinikovaya area). Stratigraphically the most complete profiles (with the presence of Frasnian stage and Lower Famenian substage) are observed in the east of the site's territory adjacent to Kipievskaya terrace. A significant thickness reduction of the play in well profiles of the western part of the site due to its stratigraphic incompleteness is typical of shallow marine shelf deposits. The profile gradually loses first its Zadonian horizon (No. 5 Nizevaya well), and next the entire Lower Famenian substage (No. 1 UstTsilemskaya well and No. 40 Khabarikhinskaya well). In well profiles of the Nizevaya area, the Famenian stage is represented by low-thickness Zadonian horizon of the Lower Famenian substage. In profiles of wells drilled in the western part of the site (No. 1 Ust-Tsilemskaya well and No. 40 Khabarikhinskaya well), the Lower Famenian deposits

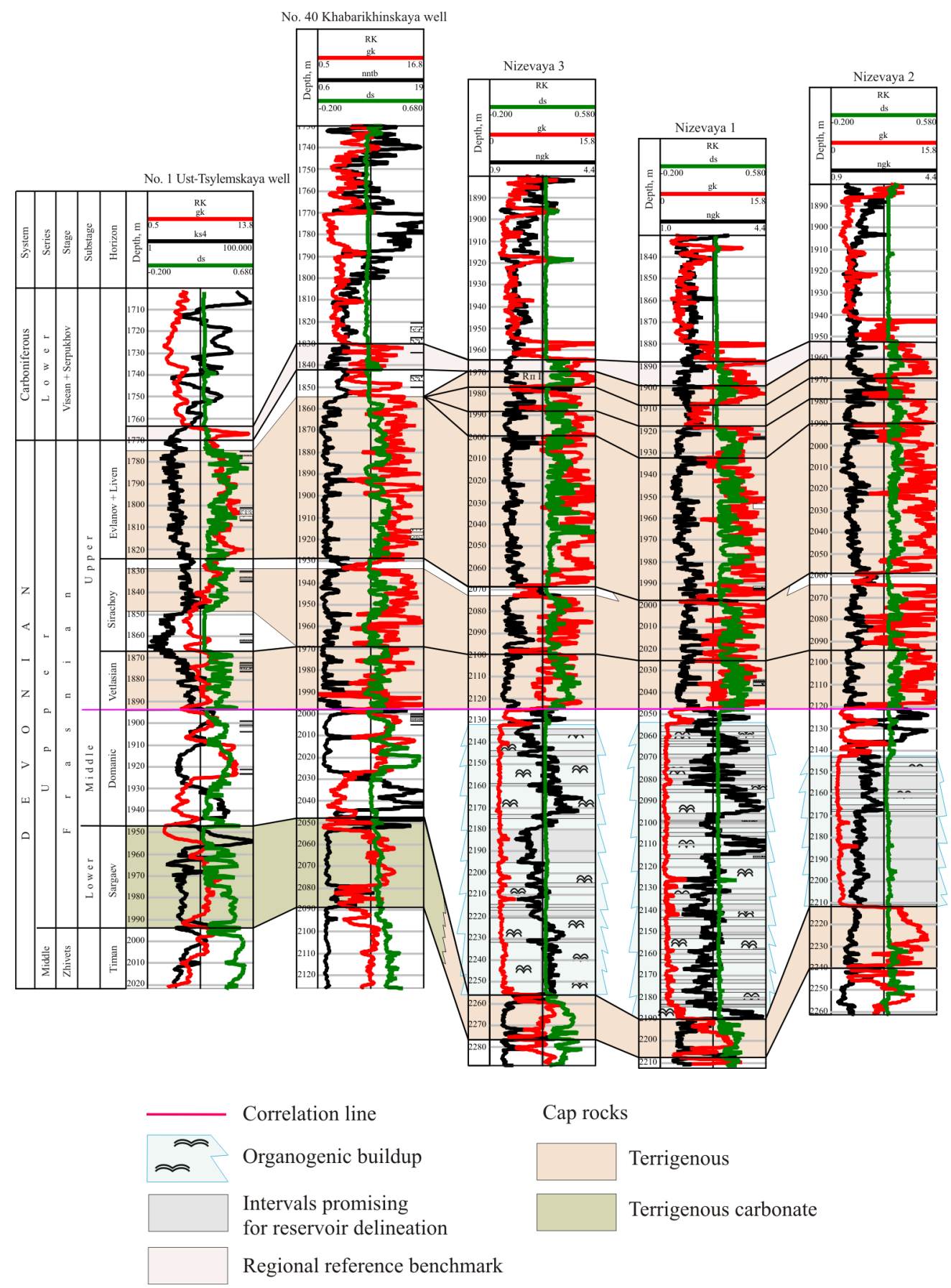

Fig. 2. Correlation pattern for Upper Devonian deposits 
are completely absent. Thickness of the play ranges from $224 \mathrm{~m}$ (No. 1 Ust-Tsilemskaya well) to $476 \mathrm{~m}$ (No. 1 Dvoinikovaya well). In the Domanic horizon profile, carbonate rocks prevail. In the bottom of the horizon, a band can be discerned (along the core of No. 1 Sosyanskaya well), made up of limestone: darkish gray, close-grained, sparsely clayey, dolomitized, pyritized, recrystallized, dense, strong, expressed in high values on curves obtained by neutron gamma-ray logging (NGRL) and AR, marked with color on the correlation pattern. The overlying profile is distinguished by prevalence of terrigenous rocks. The Vetlasian clayey band can also be clearly traced and outstands in the profile due to its high gamma-ray logging and induced potential logging values, low neutron gamma-ray logging and AR values. In the top of Sirachoy horizon, a 3-4 m thick sandyaleurolite band is distinguished.

In Severo-Tebuksky site in profiles of No. 93 Kabantyskaya well, No. 80 Kykaelskaya well and No. 52 Vanyuskaya well, the Domanic-Famenian interval is represented by the Domanic horizon of the Middle Frasnian substage, Vetlasian and Sirachoy, undivided Evlanov and Liven horizons, Upper Frasnian substage, Lower and Middle substages of the Famenian stage. The Lower Famenian substage is represented by the Volgograd, Zadonian and Yelets horizons, the Middle Famenian substage - by Ust-Pechora horizon. In profiles of No. 10 Timanskaya well, No.1 Porozhskaya well and No. 1 Ayuvinskaya Pechora-Petroleum well, the Famenian formations are only represented by the deposits of the Lower substage. Thickness of the play ranges from $506 \mathrm{~m}$ (No. 1 Porozhskaya well) to $763 \mathrm{~m}$ (No. 93 Kabantyskaya well).

In terms of geophysical likeness, typical configuration of well logging curves, and stratigraphic completeness, taking into account the facial analysis, three types of profile have been distinguished in the strata under study. Deposits of Domanic, Vetlasian ages, and also of Sirachoy and Evlanov ages in No. 93 Kabantyskaya and No. 52 Vanuyskaya wells, have formed in the zone of condensed (Domanicoid) deposits and clayey-carbonate filling strata. Profile of No. 10 Timanskaya well is typical for deposits formed in the carbonate formation of shallow marine shelf. The same type of profile was determined in the Sirachoy-Yelets terrigenous-carbonate strata in No. 1 Porozhskaya and No. 1 Ayuvinskaya Pechora-Petrolium wells, and also in the Liven-Ust-Pechora interval in No. 80 Kykaelskaya and No. 52 Vanyunskaya wells and in the strata overlaying the reef formations in No. 93
Kabantyskaya well. The development zone of reef systems, condensed (Domanicoid) deposits and filling strata is represented by reef rocks of the Liven horizon in the profile of No. 93 Kabantyskaya well.

\section{Geochemical Survey}

This paper provides the results of geochemical survey of Upper Devonian reef deposits in wells drilled in the territory of Moroshkinsky, Ust-Tsilemsky and Severo-Tebuksky sites. A summary geochemical description of the profiles of interest is presented in the table. The basis core analysis has been performed using the methods of luminescent bituminology, including determination of the content of organic carbon $\left(\mathrm{C}_{\text {org }}\right)$ in the rocks, and rock pyrolysis using Rock Eval method. The bitumoid molecular structure was studied using the method of IR spectroscopy [19], fractional composition - using thin layer chromatography [20]. The composition of biomarker carbohydrates (n-alkanes, isoprenoids) has been determined using the method of gas-liquid chromatography [21]. The organic matter has been also examined microscopically in slices after the method by E.S. Larskaya [22]. Literature [23-31] was used to assist interpretation of the geochemical survey.

$\mathrm{C}_{\text {org }}$ content in rocks (by median values) gradually decreases up the stratigraphy from Domanic deposits $(0.86 \%)$ to $0.07 \%$ in the Zadonian horizon and $0.22 \%$ in the Yelets horizon (fig. 3). Content of oil sequence hydrocarbons in rocks (pyrolytic parameter $S_{1}$ ) is measured unidirectionally: from $0.6 \mathrm{mg} / \mathrm{g}$ of rock (median value for Domanic deposits) to $0.07-0.08 \mathrm{mg} / \mathrm{g}$ in Zadonian and Yelets horizon rocks.

Oil source rocks represented by clayey limestone and inter-reef facies dolomites have been encountered mostly in the Domanic, Sirachoy, Evlanov and Liven horizons of Frasnian stage. $44 \%$ of the studied samples belong to this type of rocks.

Value $S_{2}$ descriptive of the remaining oil generation potential of rocks is high in Domanic deposits $\left(S_{2}\right.$ median values $\left.-6.9 \mathrm{mg} / \mathrm{g}\right)$. In undivided Domanic-Vetlasian deposits, $S_{2}$ goes down to the median value of $1.4 \mathrm{mg} / \mathrm{g}$ of rock and until Yelets horizon does not exceed $0.3 \mathrm{mg} / \mathrm{g}$ per rock.

The omnipresent migratory bitumoid can be identified micropetrographically by location in microfractures and intergranular space. The concentration of chloroform extracted bitumoid $\left(\mathrm{B}_{\mathrm{chl}}\right)$, based on the data of luminescent bituminological analysis, varies from trace quantities $(0.0001 \%)$ to high values $(3.75 \%)$. 
Rock geochemistry

\begin{tabular}{|c|c|c|c|c|c|c|c|}
\hline \multirow[b]{2}{*}{ Geological time } & \multirow[b]{2}{*}{ Lithology } & $\begin{array}{l}\mathrm{C}_{\text {org, }} \% \\
\text { per rock }\end{array}$ & $\begin{array}{l}\mathrm{B}_{\text {chl, }} \% \\
\text { per rock }\end{array}$ & $\begin{array}{l}S_{1}, \mathrm{mg} / \mathrm{g} \\
\text { rock }\end{array}$ & $\begin{array}{l}S_{2}, \mathrm{mg} / \mathrm{g} \\
\text { rock }\end{array}$ & \multirow{2}{*}{$\begin{array}{c}T_{\max }, \\
{ }^{\circ} \mathrm{C}\end{array}$} & \multirow{2}{*}{$\begin{array}{l}\text { Catagenesis } \\
\text { gradation } \\
\text { range }\end{array}$} \\
\hline & & \multicolumn{4}{|c|}{$\begin{array}{l}\text { minimum } \\
\text { maximum } \\
\text { median }\end{array}$} & & \\
\hline \multirow{3}{*}{$\mathrm{D}_{3} \mathrm{dm}$} & \multirow{3}{*}{$\begin{array}{l}\text { Limestones, marls, } \\
\text { dolomites, argillites }\end{array}$} & 0.02 & 0.0009 & 0.04 & 0.11 & \multirow{3}{*}{$414-451$} & \multirow{3}{*}{$\mathrm{PC}_{3}-\mathrm{MC}_{2}$} \\
\hline & & 9.4 & 2.5 & 6.30 & 76.56 & & \\
\hline & & 1.26 & 0.09 & 0.60 & 6.92 & & \\
\hline \multirow{3}{*}{$\mathrm{D}_{3} \mathrm{dm}+\mathrm{vt}$} & \multirow{3}{*}{$\begin{array}{l}\text { Argillites, aleurolites, } \\
\text { sandstones }\end{array}$} & 0.86 & 0.0009 & 0.10 & 0.47 & \multirow{3}{*}{$438-440$} & \multirow{3}{*}{$\mathrm{MC}_{1}$} \\
\hline & & 0.86 & 0.01 & 0.11 & 2.27 & & \\
\hline & & 0.86 & 0.006 & 0.11 & 1.37 & & \\
\hline \multirow{3}{*}{$\mathrm{D}_{3} \mathrm{src}+\mathrm{vt}$} & \multirow{3}{*}{ Argillites, dolomites } & 0.23 & 0.0002 & 0.06 & 0.28 & \multirow{3}{*}{438} & \multirow{3}{*}{$\mathrm{MC}_{1}$} \\
\hline & & 0.72 & 0.02 & 0.14 & 0.38 & & \\
\hline & & 0.48 & 0.0019 & 0.10 & 0.33 & & \\
\hline \multirow{3}{*}{$\mathrm{D}_{3} \mathrm{src}$} & \multirow{3}{*}{$\begin{array}{l}\text { Limestones, sandstones, } \\
\text { dolomites }\end{array}$} & 0.02 & 0.0002 & 0.08 & 0.11 & \multirow{3}{*}{$421-436$} & \multirow{3}{*}{$\mathrm{PC}_{3}-\mathrm{MC}_{1}$} \\
\hline & & 0.65 & 0.12 & 0.25 & 4.07 & & \\
\hline & & 0.19 & 0.001 & 0.09 & 0.22 & & \\
\hline \multirow{3}{*}{$\mathrm{D}_{3} \mathrm{ev}$} & \multirow{3}{*}{$\begin{array}{c}\text { Aleurolites, argillites, } \\
\text { limestones, sulfate clay rock }\end{array}$} & 0.09 & 0.0001 & 0.00 & 0.00 & \multirow{3}{*}{$437-490$} & \multirow{3}{*}{$\mathrm{MC}_{1}-\mathrm{MC}_{4}$} \\
\hline & & 0.25 & 0.0025 & 0.03 & 0.13 & & \\
\hline & & 0.17 & 0.0006 & 0.02 & 0.07 & & \\
\hline \multirow{3}{*}{$\mathrm{D}_{3} \mathrm{ev}+\mathrm{lv}$} & \multirow{3}{*}{$\begin{array}{l}\text { Limestones, dolomites, } \\
\text { aleurolites, sandstones, } \\
\text { marls }\end{array}$} & 0.03 & 0.0000 & 0.04 & 0.07 & \multirow{3}{*}{435} & \multirow{3}{*}{$\mathrm{MC}_{1}$} \\
\hline & & 0.86 & 0.08 & 0.81 & 17.83 & & \\
\hline & & 0.24 & 0.0006 & 0.10 & 0.23 & & \\
\hline \multirow{3}{*}{$D_{3} z d$} & \multirow{3}{*}{ Limestones } & 0.04 & 0.0001 & 0.07 & 0.20 & \multirow{3}{*}{$441-446$} & \\
\hline & & 0.10 & 0.08 & 0.09 & 0.22 & & $\mathrm{MC}_{2}$ \\
\hline & & 0.07 & 0.01 & 0.08 & 0.21 & & \\
\hline & & 0.13 & 0.00 & 0.04 & 0.13 & & \\
\hline $\mathrm{D}_{3} \mathrm{el}$ & Limestones, dolomites & 0.31 & 0.24 & 1.35 & 1.59 & $407-443$ & $\mathrm{PC}_{3}-\mathrm{MC}_{1}$ \\
\hline & & 0.22 & 0.0009 & 0.07 & 0.25 & & \\
\hline
\end{tabular}

N o t e : $\mathrm{C}_{\text {org }}$ - organic carbon content; $\mathrm{B}_{\mathrm{chl}}$ - chloroform extracted bitumoid content; $S_{1}, S_{2}, T_{\max }$ - pyrolytic parameters.

Geochemistry of the Upper Devonian reef deposits is further detailed below to help evaluate their prospects and hydrocarbon potential.

Domanic horizon rocks are represented by limestones in No. 1 and No. 4 wells of Nizevaya area, in No. 1 Sosyanskaya well, No. 1 Ust-Tsilemskaya well of Ust-Tsilemsky site, by marls in No. 2 SeveroKomandirshorskaya well of Moroshkinsky site, by alternation of terrigenous and carbonate rocks in No. 1 Dvoinikovaya well and No. 10 Timanskaya well of Severo-Tebuksky site.

Syngenetic organic matter is observed in slices as clots and microveinlets of colloform sapropel organic matter and carbon-bearing detritus. Microfractures and intergranular space contain adhesions of bituminous matter. $\mathrm{C}_{\mathrm{org}}$ content widely ranges: from 0.02 to $9.4 \%, \mathrm{C}_{\text {org }}$ median value is $1.3 \%$.

The highest $\mathrm{C}_{\text {org }}$ concentrations (3-9\%) are found in marls of No. 10 Timanskaya well which possesses a rich generation potential (27.4 to $76.6 \mathrm{mg} / \mathrm{g}$ rock) that didn't have the time to fully realize as the rock maturity corresponds to protocatagenesis stage $\left(\mathrm{PC}_{3}\right)$. The same area exhibits high content of bituminous matter
( $\beta$ ranges from 15 to $27 \%$ ) caused by both syngenetic resinous-asphaltenic bitumoids of the early generation stage and migratory (allochtonous) components. Pyrolytic data suggests that Domanic deposits of No. 10 Timanskaya well in the territory of Severo-Tebuksky site contain a hydrocarbon accumulation zone $\left(S_{1}-1.9-6.3 \mathrm{mg} / \mathrm{g}\right.$ rock).

In other wells, Domanic horizon rocks are less bituminous: $\mathrm{B}_{\text {chl }}$ content is maximum $0.156 \%, S_{1}-$ less than $0.5 \mathrm{mg} / \mathrm{g}$ rock. The remaining potential corresponds to the "satisfactory" category $\left(S_{2}=2.2-3.5 \mathrm{mg} / \mathrm{g}\right)$ in certain interbeds of No. 1 Dvoinikovaya well (2363.4-2367.2 m) and No. 1 Sosyanskaya well $(2257.4 \mathrm{~m})$ of Ust-Tsilemsky site, and in other cases to the "poor" category (does not exceed $0.6 \mathrm{mg} / \mathrm{g}$ rock).

In undivided Domanic-Vetlasian deposits represented by terrigenous rocks in No. 4 Nizevaya well of Ust-Tsilemsky site, the content of $\mathrm{C}_{\text {org }}$ amounts to $0.86-1.3 \%$, bitumoids are oxidized, $\mathrm{B}_{\text {chl }}$ concentration does not exceed $0.01 \%$, the concentration of alcohol-benzol extracted bitumoids $\left(\mathrm{B}_{\mathrm{ab}}\right)$ does not exceed $0.06 \%$. In terms of molecular structure, the bitumoid appears to 
be syngenetic, formed in the initial phase of hydrocarbon generation.

Vetlasian horizon rocks have been studied in No. 10 Timan area well of Severo-Tebuksky site. $\mathrm{C}_{\text {org }}$ content amounts to $0.57 \%, \mathrm{~B}_{\text {chl }}-0.0019 \%$, $\mathrm{B}_{\mathrm{ab}}-0.005 \%$. The bitumoid is lightly oily and oxidized. Pyrolytic data suggests that rocks are poor in terms of generation potential and catagenetically immature $\left(S_{2}-0.73 \mathrm{mg} / \mathrm{g}\right.$ rock $\left.\mathrm{PC}_{3}\right)$.

Sirachoy horizon rocks have relatively low $\mathrm{C}_{\text {org }}$ concentration, ranging from $0.02-0.19 \%$ in the wells of Srednekharyaginskaya and SeveroKomandirshorskaya area of Moroshkinsky site to $0.37-0.65 \%$ in the wells of Ust-Tsilemsky site and
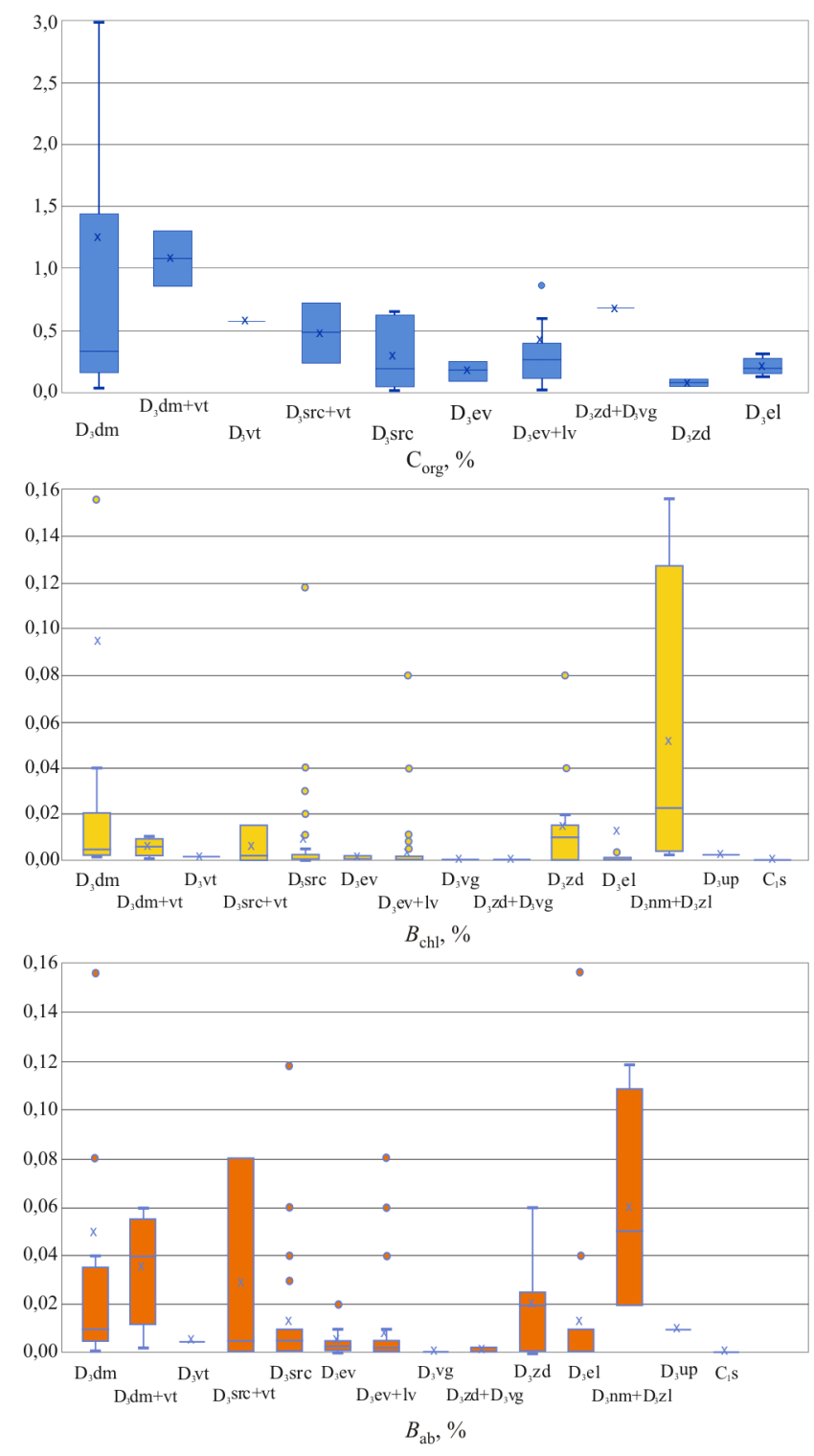

Brykalanskaya area of Ust-Tsilemsky site. Bituminous content in the rocks is also low: median content of $\mathrm{B}_{\text {chl }}$ is $0.0012 \%, \mathrm{~B}_{\mathrm{ab}}-0.005 \%$. Increasing bituminous matter content (up to $0.118 \% \mathrm{~B}_{\text {chl }}$ ) found in rocks of No. 1 Brykalanskaya well of UstTsilemsky site is due to a contribution of the migratory constituent: $\mathrm{B}_{\mathrm{chl}}$ comprises up to $70 \%$ hydrocarbons. Pyrolysis results suggest that the content of oil sequence hydrocarbons $\left(S_{1}\right)$ does not exceed $0.3 \mathrm{mg} / \mathrm{g}$ rock; content of pyrolytic hydrocarbons $\left(S_{2}\right)$ at the level of $2-4 \mathrm{mg} / \mathrm{g}$ rock at $T_{\max }=435{ }^{\circ} \mathrm{C}\left(\mathrm{MC}_{1}\right)$ substantiates satisfactory generation potential of the organic matter entering the main oil generation zone.
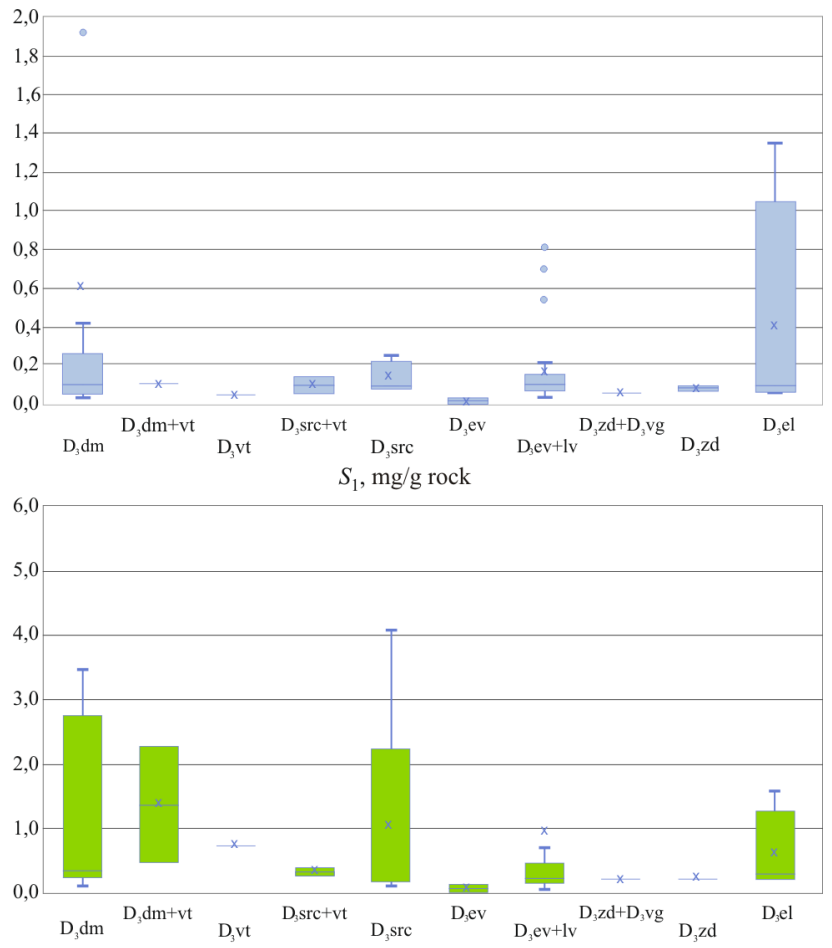

$S_{2}, \mathrm{mg} / \mathrm{g}$ rock

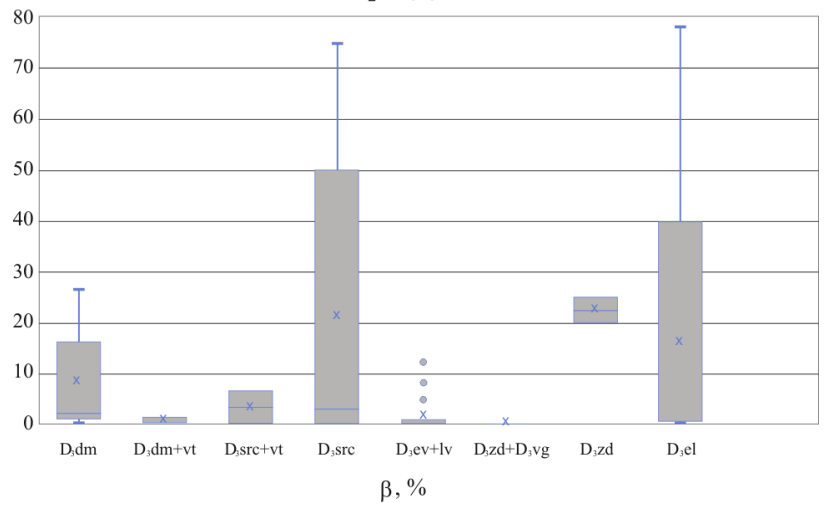

Fig. 3. Concentration distribution diagrams for $\mathrm{C}_{\text {org }}$ and bitumoids, pyrolytic indicators, bituminosity factor $(\beta)$ 
Bituminosity of the rocks from No. 2 SeveroKomandirshorskaya well and No.144 Srednekharyaginskaya well of Moroshkinsky site is much lower but is also caused by migratory components: at low $\mathrm{C}_{\text {org }}$ content $(\leq 0.04 \%)$, the bituminosity factor $\beta$ amounts to $50-75 \%$, and $\mathrm{B}_{\text {chl }}$ comprises up to $70 \%$ hydrocarbons. In terms of n-alkanes content, the bitumoids are similar to Domanic horizon bitumoids, especially in No. 144 Srednekharyaginskaya well.

In Yevlanov horizon, the concentration of organic carbon and bitumoids decrease significantly: $\mathrm{C}_{\text {org }}-$ 0.09 to $0.25 \%, \mathrm{~B}_{\text {chl }}$ content -0.0001 to $0.0025 \%$. The bitumoids are oxidized, lightly oily or oilyresinous.

In undivided Yevlanov and Liven horizons, the content of organic carbon is 0.03 to $0.86 \%$, whereas median value is $0.24 \%$. Increased concentrations are found in the rocks of No. 1 and No. 4 wells of Nizevaya area and No.1 Sosnyanskaya well of UstTsilemsky site. Migratory bitumoids are present, oxidized and in low concentrations: $\mathrm{B}_{\mathrm{chl}}$ content median value amounts to $0.0009 \%, \mathrm{~B}_{\mathrm{ab}}-0.005 \%$. Only in some of the interbeds of No. 13 SeveroKomandirshorskaya well of Moroshkinsky site, $\mathrm{B}_{\mathrm{chl}}$ content reaches $0.08 \%, \mathrm{~B}_{\mathrm{ab}}-0.06 \%$. In No. 4 Nizevaya well, catagenetically immature $\left(T_{\max }=421{ }^{\circ} \mathrm{C}\right.$ ) type III kerogen (applying Tissot and Welte (1984) classification system) is found in $\mathrm{C}_{\text {org }}$ concentration of $0.86 \%$.

In terms of fractional composition, all bitumoids are closely related: hydrocarbons account for 40-48 \%, resinous-asphaltenic compounds - for 52-60 \%. However, differences exist in molecular structure and hydrocarbon content. So, in No. 13 SeveroKomandirshorskaya well, bitumoid IR spectra of the rocks from the depth of 3872.5 and $3877.8 \mathrm{~m}$ exhibit differences in the share of unbranched saturated chains, aromaticity and degree of oxidation, which is caused by a relatively high contribution of migratory components in the bitumoid from the depth of 3872.5 m. Bitumoids from No. 31 Moroshkinskaya well, No. 144 Srednekharyaginskaya well, No. 13 Severo-Komandirshorskaya well located in the territory of Moroshkinsky site have similar configuration of IR spectra and n-alkanes molecular mass distribution curves.

Volgograd horizon rocks represented by limestones of No. 31 Moroshkinskaya well (Moroshkinsky site) have very low bituminosity $\left(\mathrm{B}_{\mathrm{chl}} \leq 0.0002 \%, \mathrm{~B}_{\mathrm{ab}} \leq 0.0006 \%\right)$.
The undivided Zadonian-Volgograd deposits represented by limestones from No. 1 well of Dvoinikovaya area at Ust-Tsilemsky site, with $\mathrm{C}_{\text {org }}$ content $=0.68 \%$, have very low bituminosity due to the presence of light and light oily bitumoid $\left(\mathrm{B}_{\mathrm{chl}}-\right.$ $0.0003 \%$ ). The rocks contain type III kerogen located in the oil window zone but with a low remaining potential $\left(S_{2} \leq 0.3 \mathrm{mg} / \mathrm{g}\right.$ rock $)$.

Rocks of Zadonian horizon are represented by limestones in No. 2 Komandirshorskaya area (Moroshkinsky site) and No. 10 Timanskaya area (Severo-Tebuksky site). The content of $\mathrm{C}_{\text {org }}$ is extremely low - less than $0.1 \%$. The concentration of bitumoids is much higher in the rocks of No. 2 Komandirshorskaya well $\left(\mathrm{B}_{\mathrm{chl}}-0.026 \%, \mathrm{~B}_{\mathrm{ab}}-\right.$ $0.036 \%$ ), whereas in the rocks of No. 10 Timanskaya well the average $B_{\text {chl }}$ concentrations amount to $0.0003 \%, \mathrm{~B}_{\mathrm{ab}}-0.001 \%$. Bitumoids of No. 2 Severo-Komandirshorskaya well are resinous, of oxidized or mixed nature, whereas No. 10 Timanskaya well bitumoids are resinous and resinous-oily and are oxidized by nature.

Bitumoids contain a high share of hydrocarbons (53\%), mostly saturated (42\%).

Isoprenoids are generally predominated by phytane ( $\mathrm{Pr} / \mathrm{Ph}$ 0.7-0.8). Low values of isoprenoid to n-alkanes ratios are an evidence of a rather significant maturation of the organic matter.

Yelets horizon rocks are represented by limestones, clayey to various extent, with interbeds of marls and dolomites, and have relatively low concentrations of organic carbon $\left(\mathrm{C}_{\text {org }}-0.3\right.$ to $0.31 \%$, median value $-0.25 \%$ ), with a direct dependence observed between concentration of $\mathrm{C}_{\text {org }}$ and bitumoids. Based on the pyrolysis data, the organic matter in all studied samples belongs to type III (humic) whose catagenetic maturity corresponds to substages $\mathrm{PC}_{3}-\mathrm{MC}_{1}$.

Values of pyrolytic parameters in the play are generally low: $S_{1}-0.07$ to $0.15 \mathrm{mg} / \mathrm{g}, S_{2}-$ less than $0.3 \mathrm{mg} / \mathrm{g}$ rock. An exception is No. 13 SeveroKomandirshorskaya well of Moroshkinsky site with a bituminous interbed in the interval of 3656.2-3667.2 m, caused by a high share of epigenetic components $\left(\mathrm{B}_{\mathrm{chl}}\right.$ concentration is $0.235 \%, \beta-78 \%, S_{1}-$ $1.4 \mathrm{mg} / \mathrm{g}$ rock).

All bitumoids are oxidized, except for the limestone bitumoid from the interval within 3649.6$3667.2 \mathrm{~m}$ in No.13 Severo-Komandirshorskaya area of Moroshkinsky site. Apart from high 
concentrations $\left(\mathrm{B}_{\mathrm{chl}}-0.235 \%, \mathrm{~B}_{\mathrm{ab}}-0.156 \%\right)$, it has a resinous-asphaltenic composition and mixed nature (neutrality factor - 1.51), high bituminosity factor (78\%), relatively high pyrolytic parameters $\left(S_{1}-\right.$ $1.4 \mathrm{mg} / \mathrm{g}, S_{2}-1,6 \mathrm{mg} / \mathrm{g}$ rock) corresponding to the zone of hydrocarbons microaccumulation.

Ust-Pechora horizon rocks are represented by limestone in No. 13 Moroshkinskaya well, containing oily-resinous (migratory) bitumoid in low concentration $\left(\mathrm{B}_{\mathrm{chl}}-0.0025 \%\right)$.

In Numylg and Zelenets horizons, rock bituminosity is higher than in the underlying limestones of Ust-Pechora horizon: $\mathrm{B}_{\mathrm{chl}}-$ up to $0.04 \%, \mathrm{~B}_{\mathrm{ab}}-$ up to $0.08 \%$. Bitumoids are mainly oxidized and resinous. In fractional composition, shares of saturated hydrocarbons and heavy resins are nearly equal (32-37\%), with an aromatic fraction and asphaltenes accounting for $12 \%$ each.

No. 31 Moroshkinskaya well contains syngenetic organic matter represented by particles of algal detritus, disperse spots and colloform clots of sapropel organic matter.

\section{Production Log Tests}

Based on the integral analysis of the results of laboratory analysis of the core and production log test materials, reservoirs have been delineated; an evaluation of their quantitative parameters and fluid content has been made.

For well logging interpretation, literature [32-39] was used.

Porosity factor has been selected as the criterion for evaluation of rock reservoir properties. Porosity was determined by neutron gamma-ray logging following the method of two guide formations using the dependencies developed by JSC KamNIIKIGS.

Petrophysical support of well logging data interpretation has been based on the core analysis data. Well logging data interpretation was performed in order to evaluate the calculation parameters for delineation of reservoir beds in the productive intervals. Evaluation of quantitative parameters of carbonate reservoirs was based on the results of standard core analysis: effective porosity, absolute permeability to gas, and volumetric density.

Evaluation of reservoirs in the Upper Devonian play and the nature of their distribution in the area and in the profile is mostly based on the production $\log$ tests. Well logging data was used for forecasting the reservoir fluid content. Distinction between water-saturated and oil-saturated reservoir beds in promising intervals has been performed on a qualitative level using the normalizing method taking into account the results of open hole assay and cased hole tests [40].

In the territory of Moroshkinsky site, well logging and core analysis have been performed for six wells drilled in the site of interest, using the data of twelve wells located beside its boundaries. Analysis of the "density-porosity" dependency in the core has shown that rock density ranges insignificantly $\left(2.44-2.83 \mathrm{~g} / \mathrm{cm}^{3}\right)$, so no dependency was found.

Determination of porosity after the NGRL procedure used the method of two guide formations. Guide formations were neat dense limestones of Zadonian deposits with $1.0 \%$ porosity and Visean age deposits with maximum $K_{\mathrm{p}}$ values [41].

For porosity calculation in promising intervals not represented in the core, based on core analysis and well logging data, a dependency was built between a double gamma-ray index of NGRL and the porosity factor $\left(\Delta I_{\mathrm{NGRL}}=f\left(K_{\mathrm{p}}\right)\right)$ for permeable interbeds (fig. 4).

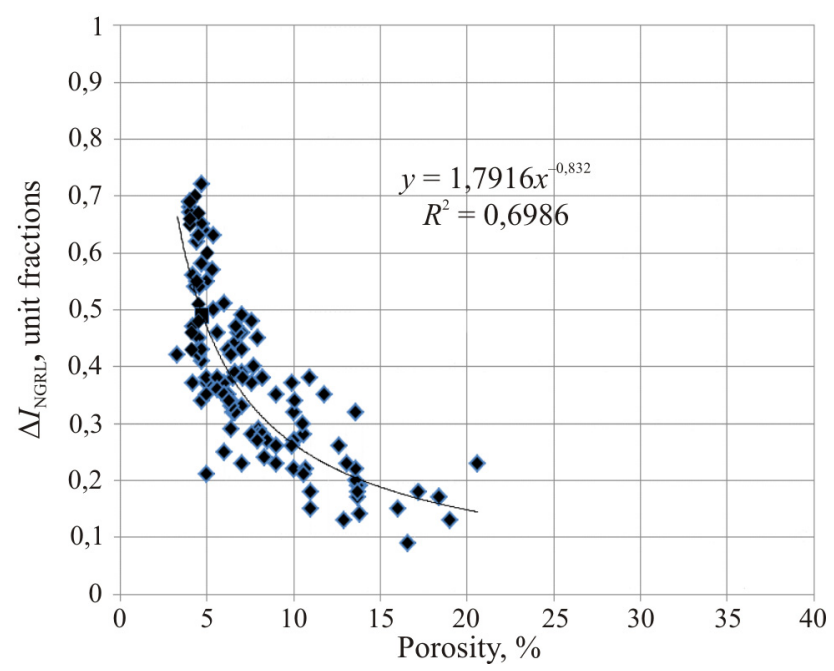

Fig. 4. $\Delta I_{\text {NGRL }}=f\left(K_{\mathrm{p}}\right)$ dependency. Moroshkinsky site

Analysis of core macro- and microdescription and the results of laboratory analysis of Upper Devonian reef deposits have shown that Moroshkinsky site reservoirs are mostly represented by low-porosity limestones, mainly clayey and closegrained, as well as organic limestones and calcareous dolomites. Rocks are mostly strong and mildly 
fractured. Fractures are mostly subhorizontal, undulating, occasionally straight, short, healed with clayey matter or calcite.

Based on the results of well logging data reinterpretation, test data analysis and assays, and core laboratory analysis, it can be concluded that in the productive parts of the profile in the territory of interest, fractured and fractured-vuggy reservoir rock prevails [42].

Profile intervals promising for delineation of reservoirs have been found in the deposits of Domanic, Sirachoy, Zadonian, Yelets, Ust-Pechora horizons and the undivided strata of NumylgZelenets time.

The fluid content of reservoir beds in the delineated intervals, based on the available data for some of the wells, enabled the use of a normalizing method, involving comparison of neutron gammaray logging curves and normalized laterolog survey curves (fig. 5). Mutual behavior of the curves provides insight on the fluid content: if the interval of interest shows an increment, there is a probability of presence of productive reservoir beds saturated with oil or gas. If the curves merge, then the beds are, most likely, water-saturated. This approach was used for evaluation of intervals in reservoirs found in carbonate rocks in the profiles of No. 31 Moroshkinskaya well, No. 2 and 13 Severo-Komandirshorskaya wells, and No. 144 Srednekharyaginskaya well.

In the profile of No. 31 Moroshkinskaya well, presumably oil-saturated reservoirs were delineated in Domanic, Sirachoy, Zadonian, Yelets, UstPechora and Numylg + Zelenets horizons. Based on the assay, mineralized water was found in Domanic deposits; no influx was discovered during formation tests in Zadonian deposits. No positive increments were found between NGRL method and laterolog survey in the reservoirs delineated in the profile of No. 144 Srednekharyaginskaya well; possibly, the reservoirs are water-saturated. Assay results in Sirachoy horizon reservoirs have registered an influx of mineralized water. In No. 2 SeveroKomandirshorskaya well profile, presumably oilsaturated reservoirs were found in the deposits of Domanic, Sirachoy, Zadonian, Yelets, Ust-Pechora and Numylg + Zelenets horizons. In the course of the testing, the Domanic deposits produced an influx of oil with a yield of $0.8 \mathrm{~m}^{3} /$ day. In No. 13 Severo-Komandirshorskaya well profile, presumably oil-saturated reservoirs were delineated in Domanic, Sirachoy, Zadonian, Yelets, UstPechora and Numylg + Zelenets horizons. Assays of Domanic deposits have found mineralized water. The difference in the evaluation by well logging and by assay may be caused by a number of reasons: failure to account for drilling-in conditions, wellbore area clogging, hydrodynamic formation characteristics, etc.

In the territory of Ust-Tsilemsky site, analysis of well logging and core materials has been performed for ten wells located in the area of interest, involving the data of five wells drilled beside its boundaries. The petrophysical "density-porosity" dependency for the core is shown in fig. 6. It is apparent that rock density varies insignificantly $\left(2.28-2.83 \mathrm{~g} / \mathrm{cm}^{3}\right)$; however, the two parameters are closely related.

Determination of porosity under NGRL procedure used the method of two guide formations and applied the obtained dependencies. Guide formations were dense limestones of Zadonian age with $1.0-1.5 \%$ porosity and terrigenous YevlanovLiven deposits with maximum $K_{\mathrm{p}}$ values. For porosity calculation in the promising intervals not represented by core, a $\Delta I_{\mathrm{NGRL}}=f\left(K_{\mathrm{p}}\right)$ dependency for permeable interbeds (fig. 7) was built on the basis of core analysis and well logging data.

Based on the obtained dependency, porosity values were calculated and reservoirs were delineated in the strata of interest.

Lithologic description, geochemical and petrophysical core analysis results in the Upper Devonian reef deposits have shown that reservoirs in Ust-Tsilemsky reference site are represented by close-grained vuggy limestones, with presence of algal limestones and organic remains, as well as replacement dolomites.

An integral analysis (well logging materials reinterpretation, use of test and assay data, core laboratory analysis) suggests that the productive parts of the profile in the area of interest exhibit prevalence of mixed type reservoirs with pore volume that includes fracture networks, intergranular voids and vuggs.

Intervals promising for reservoir delineation have been found in the Domanic horizon deposits in the profiles of most wells drilled in the area, excluding No. 1 Ust-Tsilemskaya well, No. 40 Khabarikhinskaya well and No. 1 Sosyanskaya well. From these intervals, mineralized water was obtained during assay in the 
open hole of No. 1 Brykalanskaya well and No. 1 Dvoinikovaya well. In Yelets horizon deposits, sporadic reservoir interbeds were delineated in profiles of No. 1 Brykalanskaya well $(1.5 \mathrm{~m})$ and No. 1 Dvoinikovaya well $(10.5 \mathrm{~m})$. During assay in the open hole of No. 1 Dvoinikovaya well, no influx was obtained.

Data available for some of the wells enabled use of normalizing method involving comparison of neutron gamma-ray logging curves and normalized laterolog survey curves (fig. 8). If the interval of the profile of interest shows an increment, there is a probability of presence of reservoir beds saturated with oil or gas. This approach was used for evaluation of intervals in reservoirs found in carbonate rocks of Domanic age in profiles of No. 1-5 wells of Nizevaya area. Carbonate reservoirs

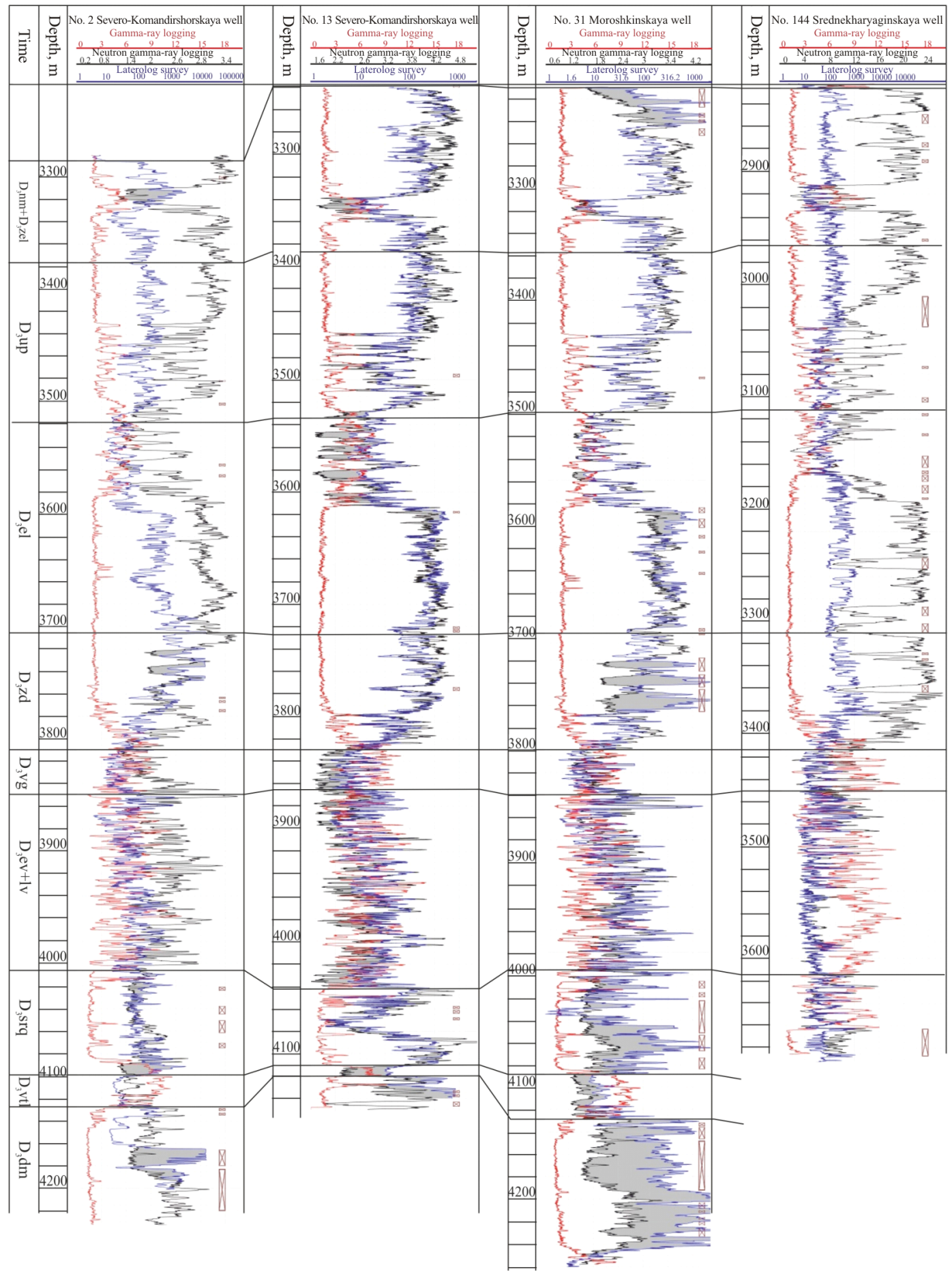

Fig. 5. Evaluation of fluid content in intervals with reservoir beds using the normalizing method. Moroshkinsky site: $\varangle$ - reservoir interval 
of Domanic age can be tentatively classified as oilsaturated. Assay and testing of deposits in this interval have not been conducted.

In the territory of Severo-Tebuksky site, the analysis of well logging and core analysis has been conducted for six wells drilled within the boundaries of the site under study, involving the data of four nearby wells.

Petrophysical dependency "density-porosity" for the core is shown in fig. 9.

Determination of porosity after NGRL procedure used the method of two guide formations and applied the obtained dependencies. Guide formations were

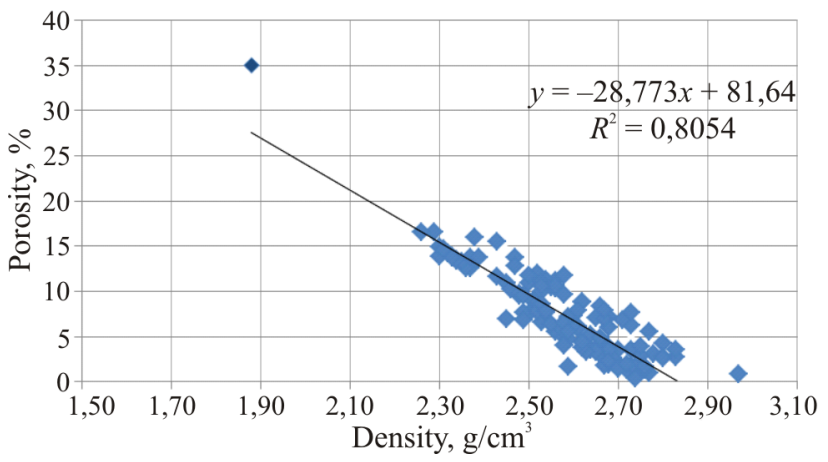

Fig. 6. Comparison of porosity and volumetric density of rock by core. Ust-Tsilemsky site

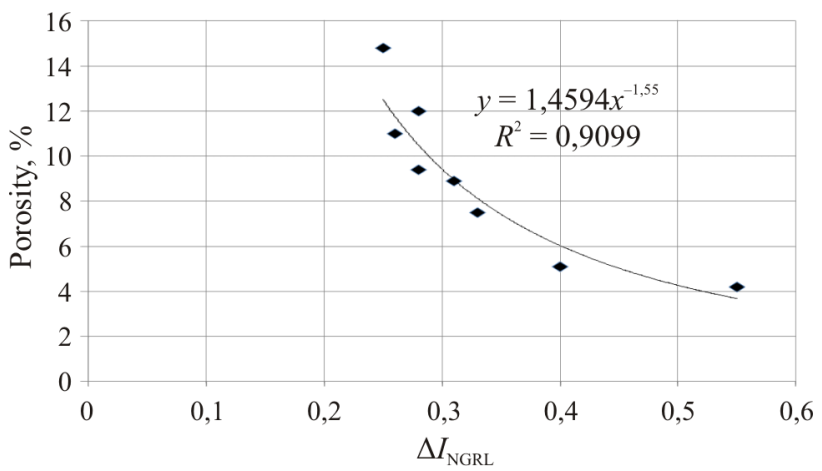

Fig. 7. $\Delta I_{\mathrm{NGRL}}=f\left(K_{\mathrm{p}}\right)$ dependency. Ust-Tsilemsky site area-extended dense limestones of Yelets horizon and terrigenous deposits of Yevlanov-Liven age with maximum $K_{\mathrm{p}}$ values. Porosities of thick beds have been determined by core and amount to $1.0-1.5 \%$ for the guide formation. Based on the NGRL data, these beds exhibit maximum NGRL values, and minimum values judging by gamma-ray logging data.

To estimate the porosity of promising intervals not represented by the core, a $\Delta I_{\mathrm{NGRL}}=f\left(K_{\mathrm{p}}\right)$ dependency was built on the basis of core analysis and well logging data for permeable interbeds (fig. 10).

Based on the obtained dependency, porosity values have been calculated and reservoirs have been delineated. In No. 1 Ayuvinskaya Pechora-Petroleum well, due to the absence of nuclear logging data, it was impossible to calculate the porosity factors; however, the assay results suggest that the intervals with reservoir beds have been delineated on a qualitative level.

The analysis of lithologic description and results of geochemical and petrophysical core tests in the Upper Devonian reef deposits have shown that the reservoirs are composed of limestones and dolomites with porosity varying within $7.97-22.22 \%$. Based on the integral analysis of the results of production log tests of the profile and core analysis, it can be assumed that the productive parts of the profile are dominated by mixed type reservoirs with pore volume that includes fracture networks, intergranular voids and vuggs [42].

Intervals promising for reservoir delineation have been found in the Domanic, Sirachoy and YevlanovLiven age. Sporadic reservoir interbeds were determined in profiles of No. 80 Kykaelskaya well in the deposits of Zadonian and Yelets horizons, and in the profile of No. 93 Kabantyskaya well in UstPechora horizon. During assay in the open hole of No. 1 Ayuvinskaya Pechora-Petroleum well, mineralized water was obtained from the Domanic and Sirachoy horizons reservoir interval.

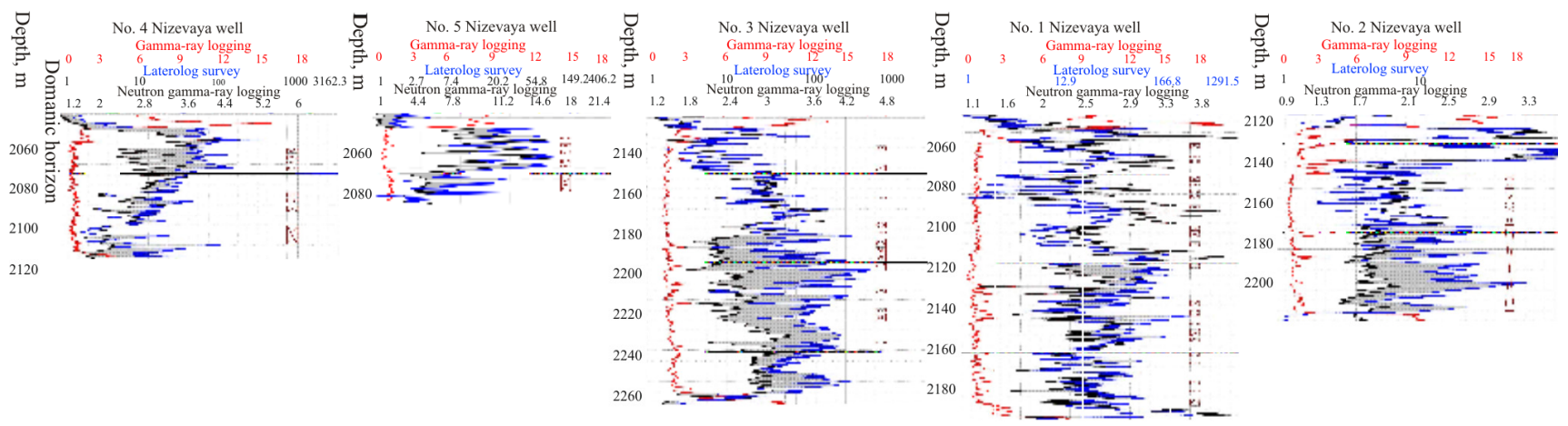

Fig. 8. Evaluation of fluid content in intervals with reservoir beds using the normalizing method.

Ust-Tsilemsky site: $\varangle$ - reservoir interval 


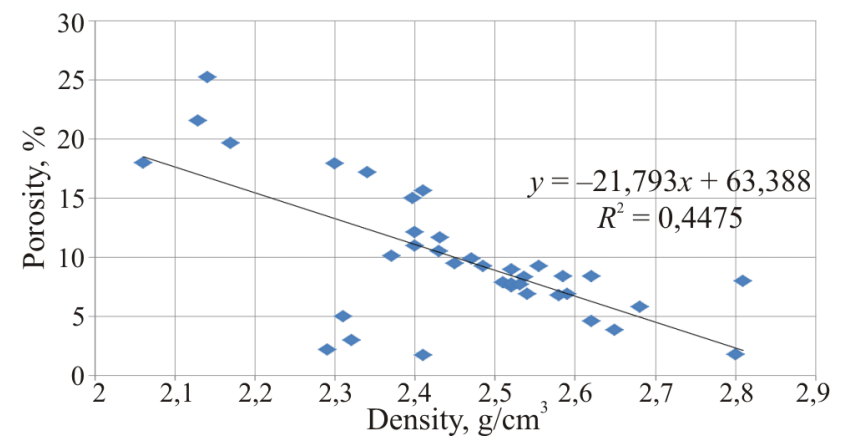

Fig. 9. Comparison of porosity and volumetric density of rock by core. Severo-Tebuksky site

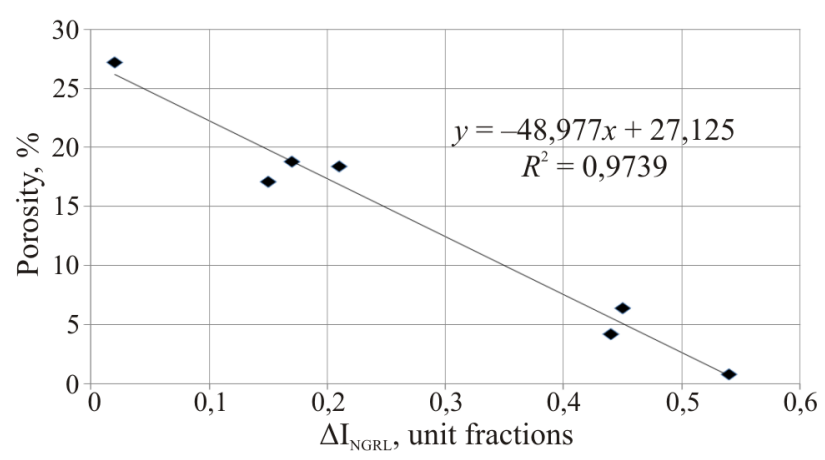

Fig. 10. $\Delta I_{\mathrm{NGRL}}=f\left(K_{\mathrm{p}}\right)$ dependency.

Severo-Tebuksky site

It is difficult to give a reliable estimation of fluid content in carbonate reservoirs due to the lack of information.

\section{Conclusions}

The following conclusions can be made on the basis of the presented materials:

1. Domanic horizon deposits contain organic matter of mostly type II and occasionally type I, found in the oil window zone $\left(\mathrm{MC}_{1}-\mathrm{MC}_{2}\right)$. In Yevlanov horizon, type III (humic) organic matter possesses a very low generation potential despite $\mathrm{MC}_{1-2}$ catagenesis corresponding to the main oil generation phase. Organic matter in Yevlanov-Liven deposits is represented by the initial sapropel (Severo-Komandirshorskaya area of Moroshkinsky site) and humic material (Moroshkinsky area of Moroshkinsky site, UstTsilemskaya, Brykalanskaya, Nizevaya areas of Ust-Tsilemsky site) and in terms of maturity encompasses the catagenetic substages from $\mathrm{PC}_{3}$ in Ust-Tsilemsky site (No. 1 and 4 Nizevaya wells, No. 1 Sosyanskaya well) to $\mathrm{MC}_{2}$ in wells of Severo-Komandirshorskaya area of
Moroshkinsky site. Rocks of Zadonian and Volgograd horizons are in the main oil generation area $\left(\mathrm{MC}_{2}\right)$, albeit poor in organic matter. Yelets horizon limestones from No.1 Dvoinikovaya well (Ust-Tsilemsky site) contain type III (humic) organic matter but are catagenetically immature $\left(\mathrm{PC}_{3}\right)$; in No. 13 Severo-Komandirshorskaya well (Moroshkinsky site) they belong to the oil window zone $\left(\mathrm{MC}_{1}\right)$.

2. Bitumoid microaccumulation (high concentration) zones are related to the development zones of oil source rocks and can be delineated in the Domanic horizon of No. 1 Sosyanskaya well and in the Sirachoy horizon of No. 1 Brykalanskaya well (Ust-Tsilemsky site), No. 10 Timanskaya well (Severo-Tebuksky site). In No. 13 well of SeveroKomandirshorskaya area (Moroshkinsky site), microaccumulation zones were traced in YevlanovLiven deposits and in the Yelets horizon. The bitumoids mostly have hydrocarbon-resinous content (hydrocarbon content is 26 to $67 \%$, resin content is 28 to $58 \%$ ).

3. Sequential analysis of bitumoid content in rocks of various geological ages shows surprising constancy of their fractional content $\mathrm{B}_{\mathrm{chl}}$ : it exhibits a sustainably high share of hydrocarbon fractions (40-72\%), among which both saturated and aromatic constituents can prevail. Similar compositions and distributions of saturated hydrocarbons in the transition from underlying to overlying horizons suggest presence of a vertical migration and a common genetic source.

4. Based on the pyrolysis results, a low oil source potential has been established for most of the studied territories. Domanic horizons in No. 4 Nizevaya well and No. 10 Timanskaya well have a rich potential. Sirachoy and Vetlasian horizons of No. 1 Dvoinikovaya well and No.1 Brykalanskaya well, as well as Domanic horizon of No. 1 Sosyanskaya well in the territory of Ust-Tsilemsky site, have average and satisfactory potential.

5. Carbonate reservoirs have complex structure of voids; they manifest intensive development of fractures and vuggs.

6. In the territory of the reference sites, the porosity and permeability properties of reservoirs were found to be vastly variable.

7. Reinterpretation of well logging materials has revealed ambiguity in the established net thicknesses. 


\section{References}

1. Shein V.S. Geologiia i neftegazonosnost Rossii [Geology and oil and gas potential of Russia]. Moscow, VNIGNI, 2012, 848 p.

2. Belonin M.D., Prishchepa O.M., Teplov E.L. et al. Timano-Pechorskaia provintsiia: geologicheskoe stroenie neftegazonosnost i perspektivy osvoeniia [Timan-Pechora province: geological structure of oil and gas potential and development prospects]. Saint Petersburg, Nedra, 2004, $396 \mathrm{p}$.

3. Uilson DZh. L. Karbonatnye fatsii $\mathrm{v}$ geologicheskoi istorii [Carbonate facies in geological history]. Moscow, Mir, 1980, $463 \mathrm{p}$

4. Grachevskii M.M., Berlin Iu.M., Dubovskoi I.T., Ulmishek G.F. Korreliatsiia raznofatsialnykh tolshch pri poiskakh nefti i gaza [Correlation of multifaceted strata in the search for oil and gas]. Moscow Nedra, 1969, 299 p

5. Bogdanov B.P. Osobennosti stroeniia verkhnedevonskikh karbonatnykh organogennykh postroek Timano-Pechorskoi provintsii $\mathrm{v}$ sviazi $\mathrm{s}$ perspektivami neftegazonosnosti [Structural features of the Upper Devonian carbonate organogenic structures of the Timan-Pechora province in connection with the prospects of oil and gas]. Abstract of Ph. D. thesis. Moscow, VNIGNI, 1989.

6. Bogdanov B.P., Bogatskii V.I. Paleozoiskie rify Timano-Pechorskoi provintsii i ikh neftegazonosnost [Paleozoic reefs of the Timan-Pechora province and their oil and gas potential]. Geologiia $i$ mineralno-syrevye resursy evropeiskogo severovostoka: prirodnye uglevodorody. Trudy XI Geologicheskoi konferentsii Komi ASSR. Syktyvkar, 1991, pp.136-142.

7. Gobanov L.A., Evdokimov V.B., Shutov B.S., Shuvalov G.A. Obobshchenie geologicheskikh i geofizicheskikh materialov s tseliu vyiavleniia zon $\mathrm{s}$ razvitiem lovushek neantiklinalnogo tipa [Generalization of geological and geophysical materials in order to identify areas with the development of non-anticlinal type traps]. Ukhta, $1986,118 \mathrm{p}$.

8. Parmuzina L.V. Stroenie, usloviia formirovaniia verkhnedevonskogo kompleksa Timano-Pechorskoi neftegazonosnoi provintsii i prognoz kollektorov [The structure, formation conditions of the Upper Devonian complex of the Timan-Pechora oil and gas province and reservoir forecast]. Doctor's degree dissertation Ukhta, UGTU, 2005, 446 p.

9. Solomatin A.V., Popova L.F., Zarkh V.P., Rasskazova N.B., Sennova V.F. Kompleksnoe litologo-stratigraficheskoe izuchenie devonskikh, siluriiskikh i ordovikskikh otlozhenii novykh ploshchadei Timano-Pechorskoi provintsii $\mathrm{V}$ sviazi s ikh neftegazonosnostiu [Comprehensive lithological-stratigraphic study of the Devonian, Silurian and Ordovician deposits of new areas of the Timan-Pechora province in connection with their oil and gas potential]. Ukhta, UTE, 1978, $174 \mathrm{p}$.

10. Tsyganko V.S., Beznosov P.A. Verkhnedevonskie rify Iuzhnogo Timana [Upper Devonian Reefs of South Timan]. Putevoditel polevoi ekskursii vserossiiskogo litologicheskogo soveshchaniia "Rify i karbonatnye psefitolity". Syktyvkar-Ukhta, 2010, $72 \mathrm{p}$.

11. Menner V.Vl. Rifogennye massivy i mestnye stratigraficheskie skhemy [Reef massifs and local stratigraphic patterns]. Iskopaemye organogennye postroiki $i$ drevnie knidarii. Tezisy dokladov XII Vsesoiuznogo simpoziuma po iskopaemym korallam i rifam. Sverdlovsk, 1991, pp.22-24.

12. Petrenko E.L. Geologicheskoe stroenie domanikovo-turneiskogo neftegazonosnogo kompleksa na territorii tsentralnoi chaste PechoroKolvinskogo avlakogena i prilegaiushchei chasti Khoreiverskoi vpadiny [The geological structure of the Domanik-Tournaisian oil and gas complex in the central part of the PechoraKolvinsky aulacogen and the adjacent part of the Khoreyver depression]. Ukhta, 2003, $126 \mathrm{p}$.

13. Petrenko E.L. Perspektivy poiskov zalezhei uglevodorodov $\mathrm{v}$ domanikovykh rifogennykh otlozheniiakh verkhnego devona tsentralnoi chasti Timano-Pechorskoi provintsii [Prospects for the search for hydrocarbon deposits in Domanic reef deposits of the Upper Devonian of the central part of the Timan-Pechora province]. Ukhta, 2013, 116 p.

14. Iureva Z.P., Bludov A.N. et al. Obobshchenie i analiz geologicheskikh materialov poiskovykh i razvedochnykh rabot na neft $i$ gaz na severe Timano-Pechorskoi provintsii, geologo-ekonomicheskii analiz ikh effektivnosti [Generalization and analysis of geological materials for prospecting 
and exploration for oil and gas in the north of the Timan-Pechora province, geological and economic analysis of their effectiveness]. Arkhangelsk, 1989, $182 \mathrm{p}$.

15. Iureva Z.P. Operativnoe obobshchenie materialov $\mathrm{i}$ rezultatov GRR na neft $\mathrm{i}$ gaz na severe TPP [Operational synthesis of materials and results of exploration for oil and gas in the north of the Timan-Pechora province]. Arkhangelsk, 1992, $32 \mathrm{p}$.

16. Durkina A.V. Granitsy devona i karbona v Timano-Pechorskoi provintsii [The borders of the Devonian and Carboniferous in the Timan-Pechora province]. Stratigraficheskie skhemy paleozoiskikh otlozhenii. Kamennougolnaia sistema. Moscow, Gostoptekhizdat, 1962,132 p.

17. Flügel E. Microfacies of carbonate rocks: analysis, interpretation and application. Berlin: Heidelberg Springer Verlag. 2004, $976 \mathrm{p}$.

18. Kuranova T.I. et al. Obosnovanie tektonosedimentatsionnoi modeli stroeniia territorii Timano-Pechorskoi NGP dlia utochneniia resursov nefti, gaza $i$ kondensata [Justification of the tectonic sedimentation model of the structure of the territory of the Timan-Pechora oil and gas province to clarify oil, gas and condensate]. Ukhta, 2011, 108 p.

19. Glebovskaia E.A. Primenenie infrakrasnoi spektroskopii $\mathrm{v}$ neftianoi geokhimii [The use of infrared spectroscopy in petroleum geochemistry]. Leningrad, Nedra, 1971, 140 p.

20. Metodicheskoe rukovodstvo po liuminestsentno-bituminologicheskim i spektralnym metodam issledovaniia organicheskogo veshchestva porod i neftei [Methodical guide to luminescentbituminological and spectral methods for studying the organic matter of rocks and oils]. Ed. T.A. Botneva. Moscow, Nedra, 1979, 204 p.

21. Shliakhov A.F. Gazovaia khromatografiia v organicheskoi geokhimii [Gas chromatography in organic geochemistry]. Moscow, Nedra, 1984, $222 \mathrm{p}$.

22. Larskaia E.S. Diagnostika i metody izucheniia neftegazomaterinskikh tolshch [Diagnostics and methods for studying oil and gas source strata]. Moscow, Nedra, 1983, 200 p.

23. Bazhenova T.K., Shimanskii V.K., Vasilev V.F., Shapiro A.I., Iakovleva L.A., Klimova L.I. Organicheskaia geokhimiia Timano-Pechorskogo basseina [Organic geochemistry of the TimanPechora basin]. Saint Petersburg, VNIGRI, 2008, 164 p.

24. Bushnev D.A. Geokhimicheskie usloviia formirovaniia neftei Varandei-Adzvinskoi zony Pechorskogo basseina [Geochemical conditions for the formation of oils of the Varandey-Adzvinsky zone of the Pechora basin]. Syktyvkar, 1998, 148 p.

25. Valiaeva O.V. Generatsiia i lateralnaia migratsiia neftei verkhnedevonskikh otlozhenii Khoreiverskoi vpadiny i Varandei-Adzvinskoi zony [Generation and lateral migration of oils of the Upper Devonian sediments of the Khoreyver Depression and the Varandey-Adzvinsky zone]. Syktyvkar, 2000, $143 \mathrm{p}$.

26. Danilevskii S.A. Geologo-geokhimicheskie zakonomernosti raspredeleniia neftegazonosnosti $\mathrm{v}$ osadochnom chekhle Timano-Pechorskoi provintsii [Geological and geochemical patterns of oil and gas distribution in the sedimentary cover of the Timan-Pechora province]. Abstract of Ph. D. thesis. Leningrsd, VNIGRI, 1991, $20 \mathrm{p}$.

27. Klimenko S.S., Anishchenko L.A. Osobennosti sostava, realizatsii potentsiala organicheskogo veshchestva i neftegazonosnost Timano-Pechorskogo basseina [Features of the composition, implementation of the potential of organic matter and oil and gas potential of the Timan-Pechora basin]. Geologiia $i$ geokhimiia goriuchikh iskopaemykh evropeiskogo severa rossii. Trudy Instituta geologii Komi NTs UrO RAN. Syktyvkar, 2011, pp.146-154.

28. Lopatin N.V., Emets T.P. Piroliz v neftegazovoi geokhimii [Pyrolysis in oil and gas geochemistry]. Moscow, Nauka, 1987, 144 p.

29. Oknova N.S., Kokhanova A.N. Osobennosti domanikovykh otlozhenii Timano-Pechorskoi provintsii [Features of Domanik deposits of the TimanPechora province]. Materialy VII Vserossiiskogo litologicheskogo soveshchaniia. Novorossiisk, 2013, vol.2, pp.338-341.

30. Tisso B., Velte D. Obrazovanie i rasprostranenie nefti [Oil production and distribution]. Moscow, Mir, 1981, 502 p.

31. Peters K.E., Moldowan J.M. The biomarker Guide. Interpreting molecular fossils in petroleum and ancient sediments. Englewood Cliffs. New Jersey: Prentic Hall, 1993, p.336.

32. Buriakovskii L.A., Dzhafarov I.S., Dzhevanshir R.D. Prognozirovanie fizicheskikh 
svoistv kollektorov i pokryshek nefti i gaza [Prediction of the physical properties of oil and gas reservoirs and cap rocks]. Moscow, Nedra, 1982, $200 \mathrm{p}$.

33. Darling T. Prakticheskie aspekty geofizicheskikh issledovanii skvazhin [Practical aspects of well logging]. Moscow, Premium Inzhiniring, 2008, $400 \mathrm{p}$.

34. Smekhov E.M., Kirkinskaia V.N. Karbonatnye porody-kollektory nefti i gaza [Carbonate oil and gas reservoir rocks]. Leningrad, Nedra,1981, 255 p.

35. Derevianko A.G. et al. Analiz i obobshchenie rezultatov geologo-geofizicheskikh dannykh po razvedochnym skvazhinam Permskoi oblasti [Analysis and synthesis of the results of geological and geophysical data on exploratory wells in the Perm region]. Perm, 1983, $134 \mathrm{p}$.

36. Latyshova M.G., Martynov V.G., Sokolova T.F. Prakticheskoe rukovodstvo po interpretatsii dannykh GIS [Practical guidance on the interpretation of well logging data]. Moscow, Nedra-Biznestsentr, 2007, 327 p.

37. Ellis D.V., Singer Iu.M. Well logging for earth scientists. 2007, 699 p.

38. Rider M. The geological interpretation of well logs. Second ed. Rider-French Consulting ltd, 2002.

39. Fertl W. Gamma ray spectral data assists in complex formation evaluation. Transactions.

6th European Formation Evaluation Symposium. Society of Professional Well Log Analysts, London, 1979.

40. Parshina L.M., Kuzminova I.V. Otsenka kollektorskikh svoistv i nasyshchennosti karbonatnykh otlozhenii metodom normalizatsii: metodicheskie ukazaniia [Assessment of reservoir properties and saturation of carbonate deposits by normalization method: guidelines]. UKhTA, UGTU, 2012, $8 \mathrm{p}$

41. Petersile V.I., Poroskun V.I., Iatsenko G.G. Metodicheskie rekomendatsii po podschetu geologicheskikh zapasov nefti i gaza obemnym metodom [Guidelines for calculating the geological reserves of oil and gas by the volumetric method]. Moscow, Tver, VNIGNI, 2003.

42. Matvievskaia N.D., Degtereva L.V., Krivtsov K.A. et al. Effektivnost geofizicheskikh metodov pri poiskakh rifov $\mathrm{v}$ Timano-Pechorskoi provintsii [The effectiveness of geophysical methods in searching for reefs in the Timan-Pechora province]. Trudy VNIGNI. Moscow, 1982, no. 237, pp.22-23.

43. Smekhov E.M. Zakonomernosti razvitiia treshchinovatosti gornykh porod i treshchinnykh kollektorov nefti i gaza [Patterns of development of fracturing of rocks and oil and gas fractured reservoirs]. Trudy VNIGNI. Leningrad, Gostoptekhizdat, 1961, iss.172, $146 \mathrm{p}$.

\section{Библиографический список}

1. Шеин В.С. Геология и нефтегазоносность России. - М.: ВНИГНИ, 2012. - 848 с.

2. Тимано-Печорская провинция: геологическое строение, нефтегазоносность и перспективы освоения / М.Д. Белонин, О.М. Прищепа, Е.Л. Теплов [и др.]. - СПб.: Недра, 2004. - 396 с.

3. Уилсон Дж.Л. Карбонатные фации в геологической истории. - М.: Мир, 1980. - 463 с.

4. Корреляция разнофациальных толщ при поисках нефти и газа / M.M. Грачевский, Ю.М. Берлин, И.Т. Дубовской, Г.Ф. Ульмишек. М., 1969. - С. 163-194.

5. Богданов Б.П. Особенности строения верхнедевонских карбонатных органогенных построек Тимано-Печорской провинции в связи с перспективами нефтегазоносности: дис. ... канд. геол.-мин. наук. - М.: ВНИГНИ, 1989. - 246 с.

6. Богданов Б.П., Богацкий В.И. Палеозойские рифы Тимано-Печорской провинции и их нефтегазоносность // Геология и минеральносырьевые ресурсы европейского северо-востока: природные углеводороды: тр. ХІ геологич. конф. Коми АССР. - Сыктывкар, 1991. C. $136-142$.

7. Обобщение геологических и геофизических материалов с целью выявления зон с развитием ловушек неантиклинального типа / Л.А. Гобанов, В.Б. Евдокимов, Б.С. Шутов, Г.А. Шувалов; ТПО «ВНИГРИ». - Ухта, 1986. - 118 с.

8. Пармузина Л.В. Строение, условия формирования верхнедевонского комплекса ТиманоПечорской нефтегазоносной провинции и прогноз коллекторов: дис. … д-ра геол.-мин. наук. - Ухта: УГТУ, 2005. - 446 с.

9. Комплексное литолого-стратиграфическое изучение девонских, силурийских и ордовикских отложений новых площадей Тимано-Печорской провинции в связи с их нефтегазоносностью / 
А.В. Соломатин, Л.Ф. Попова, В.П. Зарх, Н.Б. Рассказова, В.Ф. Сеннова. - Ухта: УТЭ, 1978. - $174 \mathrm{c}$.

10. Цыганко В.С., Безносов П.А. Верхнедевонские рифы Южного Тимана: путеводитель полевой экскурсии Всероссийского литологического совещания «Рифы и карбонатные псефитолиты». - Сыктывкар - Ухта, 2010. - 72 с.

11. Меннер В.Вл. Рифогенные массивы и местные стратиграфические схемы // Ископаемые органогенные постройки и древние книдарии: тез. докл. XII Всесоюзн. симп. по ископаемым кораллам и рифам. - Свердловск, 1991. - С. 22-24.

12. Петренко Е.Л. Геологическое строение доманиково-турнейского нефтегазоносного комплекса на территории центральной части ПечороКолвинского авлакогена и прилегающей части Хорейверской впадины / ГУП РК «ТП НИЦ». Ухта, 2003. - $126 \mathrm{c.}$

13. Петренко Е.Л. Перспективы поисков залежей углеводородов в доманиковых рифогенных отложениях верхнего девона центральной части Тимано-Печорской провинции / ОАО «ТП НИЦ». - Ухта, 2013. - 116 с.

14. Обобщение и анализ геологических материалов поисковых и разведочных работ на нефть и газ на севере Тимано-Печорской провинции, геолого-экономический анализ их эффективности / З.П. Юрьева, А.Н. Блудов [и др.]; ПГО «Архангельскгеология». - Архангельск, 1989. - 182 с.

15. Юрьева 3.П. Оперативное обобщение материалов и результатов ГРР на нефть и газ на севере ТПП / ПГО «Архангельскгеология». Архангельск, 1992. - 32 с.

16. Дуркина А.В. Границы девона и карбона в Тимано-Печорской провинции // Стратиграфические схемы палеозойских отложений. Каменноугольная система. - М.: Гостоптехиздат, 1962. - $132 \mathrm{c}$.

17. Flügel E. Microfacies of carbonate rocks: analysis, interpretation and application. - Berlin: Heidelberg Springer Verlag, 2004. - 976 p.

18. Обоснование тектоно-седиментационной модели строения территории Тимано-Печорской НГП для уточнения ресурсов нефти, газа и конденсата / Т.И. Куранова [и др.]; ООО «ТП НИЦ Нефтегаз». - Ухта, 2011. - 108 с.

19. Глебовская Е.А. Применение инфракрасной спектроскопии в нефтяной геохимии. Л.: Недра, 1971. - 140 с.
20. Методическое руководство по люминесцентно-битуминологическим и спектральным методам исследования органического вещества пород и нефтей / под ред. Т.А. Ботневой. - М.: Недра, 1979. - 204 с.

21. Шляхов А.Ф. Газовая хроматография в органической геохимии. - М.: Недра, 1984. - 222 с.

22. Ларская Е.С. Диагностика и методы изучения нефтегазоматеринских толщ. - М.: Недра, 1983. - 200 с.

23. Органическая геохимия Тимано-Печорского бассейна / Т.К. Баженова, В.К. Шиманский, В.Ф. Васильев, А.И. Шапиро, Л.А. Яковлева, Л.И. Климова. - СПб.: ВНИГРИ, 2008. - 164 с.

24. Бушнев Д.А. Геохимические условия формирования нефтей Варандей-Адзьвинской зоны Печорского бассейна. - Сыктывкар, 1998. - 148 с.

25. Валяева О.В. Генерация и латеральная миграция нефтей верхнедевонских отложений Хорейверской впадины и Варандей-Адзьвинской зоны. - Сыктывкар, 2000. - 143 с.

26. Данилевский С.А. Геолого-геохимические закономерности распределения нефтегазоносности в осадочном чехле Тимано-Печорской провинции: автореферат дис. ... канд. геол.-мин. наук. Л.: ВНИГРИ, 1991. -20 с.

27. Клименко С.С., Анищенко Л.А. Особенности состава, реализации потенциала органического вещества и нефтегазоносность ТиманоПечорского бассейна // Геология и геохимия горючих ископаемых Европейского Севера России: тр. Ин-та геологии Коми НЦ УрО РАН. Сыктывкар, 2011. - С. 146-154.

28. Лопатин Н.В., Емец Т.П. Пиролиз в нефтегазовой геохимии. - М.: Наука, 1987. - 144 с.

29. Окнова Н.С., Коханова А.Н. Особенности доманиковых отложений Тимано-Печорской провинции // Материалы VII Всерос. литологического совещания, 28-31 октября 2013 г. Новороссийск, 2013. - Т. 2. - С. 338-341.

30. Тиссо Б., Вельте Д. Образование и распространение нефти. - М.: Мир, 1981. - 502 с.

31. Peters K.E., Moldowan J.M. The biomarker guide. Interpreting molecular fossils in petroleum and ancient sediments // Englewood Cliffs. New Jersey: Prentic Hall, 1993. - P. 336.

32. Буряковский Л.А., Джафаров И.С., Джеваншир Р.Д. Прогнозирование физических свойств коллекторов и покрышек нефти и газа. М.: Недра, 1982. - 200 с. 
33. Дарлинг Т. Практические аспекты геофизических исследований скважин. - М.: Премиум Инжиниринг, 2008. - 400 с.

34. Смехов Е.М., Киркинская В.Н. Карбонатные породы-коллекторы нефти и газа. - Л.: Недра, 1981. $-255 \mathrm{c}$.

35. Анализ и обобщение результатов геологогеофизических данных по разведочным скважинам Пермской области / А.Г. Деревянко [и др.]; Трест «Пермнефтегеофизика». - Пермь, 1983. - 134 c.

36. Латышова М.Г., Мартынов В.Г., Соколова Т.Ф. Практическое руководство по интерпретации данных ГИС: учеб. пособие для вузов. - М.: Недра-Бизнесцентр, 2007. - 327 с.

37. Ellis D.V., Singer I.M. Well logging for earth scientists. - Springer Science + Business Media B.V., 2007. -699 p.

38. Rider $M$. The geological interpretation of well logs. - 2 ed. - Los Angeles: Rider-French Consulting ltd, 2002. $-280 \mathrm{p}$.

39. Fertl W. Gamma ray spectral data assists in complex formation evaluation // Transactions: 6th European Formation Evaluation Symposium / Society of Professional Well Log Analysts. London, 1979. - $20 \mathrm{p}$.

40. Паршина Л.М., Кузьминова И.В. Оценка коллекторских свойств и насыщенности карбонатных отложений методом нормализации: метод. указания. - Ухта: УГТУ, 2012. $-8 \mathrm{c}$.

41. Петерсилье В.И., Пороскун В.И., Яценко Г.Г. Методические рекомендации по подсчету геологических запасов нефти и газа объемным методом / НПЦ «Тверьгеофизика». - М. - Тверь: ВНИГНИ, 2003. - 260 с.

42. Эффективность геофизических методов при поисках рифов в Тимано-Печорской провинции / Н.Д. Матвиевская, Л.В. Дегтерева, К.А. Кривцов [и др.] // Тр. ВНИГНИ. - М., 1982.№ 237. - С. 22-23.

43. Смехов Е.М. Закономерности развития трещиноватости горных пород и трещинных коллекторов нефти и газа // Тр. ВНИГРИ. Л.: Гостоптехиздат, 1961. - Вып. 172. $146 \mathrm{c}$.

Please cite this article in English as:

Sosnin N.E., Kazakova T.A., Filipyeva S.G., Vasyanina D.I., Batova I.S. Geology aspects of upper Devonian reef deposits in Timan-Pechora oil and gas bearing province. Perm Journal of Petroleum and Mining Engineering, 2019, vol.19, no.4, pp.304-321. DOI: $10.15593 / 2224-9923 / 2019.4 .1$

Просьба ссылаться на эту статью в русскоязычных источниках следующим образом:

Особенности геологического строения верхнедевонских рифогенных отложений Тимано-Печорской нефтегазоносной провинции / Н.Е. Соснин, Т.А. Казакова, С.Г. Филипьева, Д.И. Васянина, И.С. Батова // Вестник Пермского национального исследовательского политехнического университета. Геология. Нефтегазовое и горное дело. - 2019. T.19, №4. - C.304-321. DOI: 10.15593/2224-9923/2019.4.1 